\title{
The Development System of Linguistic Experience on The Debate Text of Presidential Candidate of The Republic of Indonesia 2014 - 2019
}

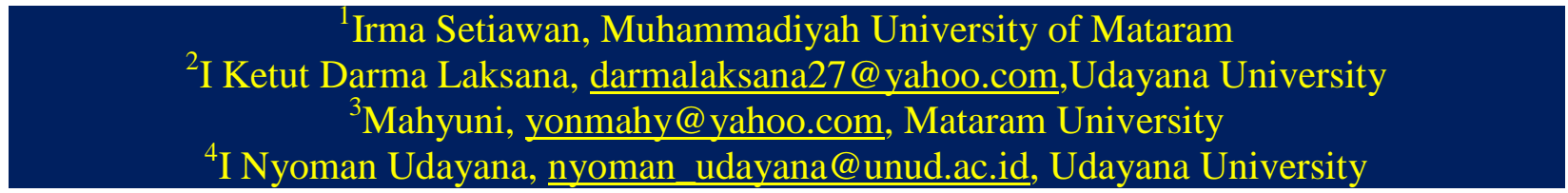

*Corresponding Author: irmasetiawan9@gmail.com

Received Date: 03-02-2018 Accepted Date: 20-03-2018 Published Date: 31-07-2019

\begin{abstract}
The presidential candidate debate text development system is a sort of linguistic experience elements reflecting the speaker's way of thinking related to the policies of the nation and state. The text development might indicate the policy intended by a presidential candidate to build the nation and state. Based upon this, there are three factors behind the selection of this topic to research; namely, empirical, practical, and theoretical factors. This study is conducted aimed at describing various issues concerning the development of the linguistic experience of the two presidential candidates in improving the national and international welfare and international politics-national resilience. Systemic Functional Linguistic (SFL) theory initiated by Halliday $(1985,1991,2004,2014)$ is used as the grounded theory in this study. This study employs qualitative descriptive approach with linguistic phenomenological paradigm. Various data types analyzed in this study include words, phrases, clauses, group phrases, and text units. The data use taken from the recorded of audio-visual Candidate Debate Text (CDT) in stage I and II. The research instruments used in this study are text validation tables and contexts. Along with some advanced techniques, documentation and observation were conducted to collect the data. Meanwhile, in processing the data collected, this study passed several stages; namely, data classification, segmentation, and codification. To analyze the data processed, this study employed several stages namely reduction, presentation, and verification. The results of this study show that Prabowo Subianto (PS) tended to use dynamic linear text development pattern, whereas Joko Widodo (JW) tended to use a constant linear text development pattern.
\end{abstract}

Keywords: development system of linguistic experience, text of debate, and Systemic Functional Linguistics (SFL)

\section{Introduction}

The presidential candidate debate is part of a set of presidential election activities in a country. The presidential candidate debate is a mandatory activity undertaken by countries holding the presidential democratic system. Debate is aimed at introducing, socializing, and giving political education to all parties involved in it. However, in some countries in the world, the political debate his actually taken place less conducive, due to various political interests. For example, presidential debate from Democrat party presidential candidate, Hillary Clinton debating with Republican presidential candidate, Donald Trump, in 2016 argued against taxation policies (Bhattarai et al. 2018), presidential political turmoil in Lebanon (Potter, 2016 ), the 
community conflict in the election of the governor of the province of Lagos, Negria (Ajilore, 2015), President Buhari's political speech in response to the parliamentary chaos in Nigeria (Koussouhon \& Dossoumou, 2015), and various political issues of presidential elections in the United States including race, group or community, handling immigrants, and so forth (Benoit \& Airne, 2005). Various examples of such political issues also exist in some areas in Asia including in Indonesia. The presidential debate in Indonesia usually raises various issues essentially consisting of three main factors, namely empirical, practical, and theoretical phenomena.

The empirical phenomena attracting attention in organizing presidential debate in 2014 were the social attitude of the language of the presidential candidates, the involvement of the media in the process of winning the presidential candidate, and the political and social conditions of the society. Various linguistic contents of the presidential candidate which are persuasive and euphemism precisely raise an attitude of excessive fanaticism in society. As a result, Indonesian society are divided into pros and cons coalition. The same thing happens to the smallest community in society, namely family life (household). The family members split into two group due to different attitudes towards and perceptions of the presidential candidates. Academicians as well as political observers, Purba (Okezone, 23/3/14) describes thes phenomena in the national media news headline entitled "Warring with Your Own Brother" which essentially alludes to horizontal conflicts of Indonesian society due to the influence of the presidential election in 2014. The involvement of media in playing political issues to favor or weaken one of the presidential candidates further aggravated the 2014 presidential site. The media tended to intervene and lead to voter perceptions through political languages. Eriyanto (2012: 32) claims that the media is only dominated by dominant groups and become a means of discrediting other groups.

Practical phenomenon in organizing presidential debate in 2014 that attracts the attention of researcher is the language practice of the presidential candidates, the procedure of debate, and the mechanism of debate broadcast on the television. Both candidates' language strategies tend to leverage personal experiences to build a nation. The contents of the debate of the presidential candidates were largely sourced from survey evidence according to their own expert team without any comparison, so it could lead to the subjective claims. The activities of the presidential debate were held by the General Election Commission (GEC) directly supervised by

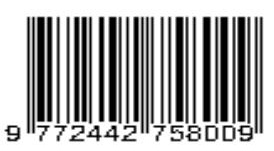


the Election Supervisory Board. Broadcasting the presidential debate must be guarded by the public. In this case, the researcher is obliged to monitor and analyze, the mechanism of organizing the event funded by the state. The researcher's attitude controlled the debate show based on article 17 paragraph 2 of the ACC No. 40 of 1999 impressing on public participation in overseeing media broadcasts, the printed andelectronic.

The theoretical phenomenon that encourages the researcher to analyze the presidential debate 2014 is the scheme of linguistic experience and the lack of some related previous research. Halliday (2014: 13) states in the study of Systemic Functional Linguistic, that linguistic experience which stems from non-linguistic experiences communicated by participants is called a text. The existence of the text cannot be interpreted without the presence of context. Therefore, linguistic experience in the study of Systematic Functional Linguistics is constructed from the text and its context with elements of analysis including: type, scope, value, and orientation. Based upon this, these recent years research on the study of texts and contexts based on Systematic Functional Linguistics Theory (SFLT) conducted: Bhattarai, et.al. (2015), Potter (2016), Ajilore (2015), Koussouhon \& Dossoumou (2015), and Benoit \& Airne (2005) are the five studies leaving gaps that have not been discovered previously, namely the debate scheme that contains the level - dominance and the range or reach of clauses of language based on the study of Systematic Functional Linguistics Theory.

The fifth methodological concept of the aforementioned research mostly refers to concept of Firth which is claimed as the most influential concept in Europe. Firth idea is dominantly influenced by some structural linguistic theories of Saussure, Hjemslev, Malinowski, and the ideology of Prague (Sinar, 2012: 14). Firth's view seeks to look at the language in its use and its functions on the basis of the various systems in the language. This is the one developed by the Pragueists who see that the function of language is derived from interrelated forms, systems (structures), mutual determination, and stratification (Young, 2011: 625).

The novelty of this research is to analyze the scheme and range of the utterances delivered by both candidates in presidential debate based on the transitivity system which includes text analysis in the form of process, participants, and circumcision. The three units of analysis of transitivity systems have analytical elements such as: (1) the process including material, mental, relational, behavioral, verbal, and existential analysis; (2) participants including the main 
participants (participants I and II) and other participants, 3) Circumstance including time and place extent, location of time and place, way, contingency, cause, angle, matter, and source. The overall analysis of the transitivity system is presented based on the analytical tools that have the nature of the process of high - low realization, the nature of single and plural participants, inclusive and exclusive. The context analysis is used to investigate ideological motives in the text of the presidential debate based on the cultural and situational context.

The expected result of this study is to obtain the schematic and range of clauses of the utterance from the linguistic presentation system of presidential candidates, namely, Prabowo Subianto (PB) and Joko Widodo (JW) on the text of the presidential debate of the Republic of Indonesia 2014 - 2019. Based upon this, the exposure of the linguistic experience is aimed at describing the transitivity system which includes analysis of processes, participants, circumstances, and the range or reach of the three elements of systemic analysis. The use of range on process, participant, and circumstance analysis can represent the focus and direction of the policies of both candidates.

Based on the above empirical, practical, and theoretical phenomena, this study becomes very interesting to conduct using on the theory of Systematic Functional Linguistics. The researcher analyzed the function of linguistic experience exposure. Analyzed the ideological contents based on the social context of the text. The current research presence is intended to explore and map the scheme and content of the 2014 presidential debate text. In addition, the study of the text of political debate based on Systematic Functional Linguistics Theory has never been conducted by any previous researchers so this study is expected to be one of the analytical formulas and additional variations to the method of discourse investigation, especially to oral text, such as the text of the presidential debate.

\section{Research Method}

The research approach used in this study is qualitative research design aimed at describing and analyzing transitivity system, situational context, and cultural context. Hence, detailed understanding of the scheme and range of discussion of the two candidates during the debate can be obtained.

The data in the form of oral data were transcribed wholly so that the data in the form words, phrases, group phrases, clauses, and text units could be obtained. ACC the data come from the

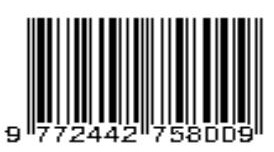


utterances of the candidates during the debate. Data transcripts or CDT 2014 serve as the primary data of research because the data were obtained by the researcher directly from the data source, while the secondary data are in the form of supporting data obtained from written text or library.

The data source in this study was adobted from the audio-visual tape (video) of 2014 presidential debate broadcast through television. The debate video was divided into five rounds, namely, the first round of presidential was stage and vice-presidential debate, the second round was the first stage of the debate, the third round of the second stage of the debate, the fourth round was the first stage of the debate, and the fifth round was stage the presidential and vicepresidential debate.

The research instrument was divided into two; namely, the main and supporting instruments. The main instrument in this study is the researcher himself as human resource in the study. In this case the researcher used a validation instrument in the form of a functional validation table to observe the systematic functioning of every text forming element, such as words, phrases, groups, and clauses. Furthermore, supporting instruments are more in the form of supporting equipment in searching, collecting, determining, and analyzing data.

This research enploxed to descriptive method because the data were collected qualitatively by describing the language scheme and the subject of presidential talk on debate text of 2014. To describe text units and context in 2014 presidential debate text, several data collection techniques were used; namely, documentation and observation techniques. The method of analysis used by the researcher was inductive method, meaning that the way of thinking in this study departs from the rules that are specific to determine the general principle. The analytical technique used was qualitative technique because the collected data were processed and analyzed descriptively. Miles and Huberman (1992: 16) propose an interactive and comprehensive step of analysis covering the steps of data reduction, presentation, and verification.

In this research the data are presented using formal and informal methode. The informal method is intended to present all forms of speech in the form of numbers and descriptions of words, phrases, group phrases, clauses, units of text, and text. Formal methode is intended to present the result of research in the form of symbols or signs (Mahsun, 2007: 123 and Sudaryanto, 015: 144). 


\section{Theoritical Framework}

Systemic Functional Linguistics Theory (SFLT) is a model of linguistic study developed by Halliday $(1985 ; 1991 ; 2004 ; 2014)$ of the University of Sydney - Australia. Halliday adopted many teaching linguistic theories from European linguists, such as Firth (English). The development of Halliday's ideology is dominantly influenced by the linguistic principle of the Prague Flow. Young (2011: 625) describes the views of the Ideology of Prague on several things in linguistic theory, namely: (a) the view of language as an interconnected network, (b) the view of language as a system consisting of multilevel or stratified sub-systems , (c) the more emphasis on the functional aspects of the language, and (d) the existence of view of towards the form coming from the function. SFLT mainly focus on language relation with context. SFLT is based on two basic concepts that distinguish it from other linguistic theories, namely; (a) language is a social phenomenon in the form of social semiotics and (b) language is a text that is in strong relation with the social context so that the study of language is never independent on the social context. The SFLT has been discussed in the last four editions of Halliday's book (1985; 1991; 2004; 2014).

Text development system is a network where the patterns of information developments from one clause to another clause are loaded, contributing to a unity of comprehensive information. The analysis of the pattern of text development can explain the participants' way of thinking in preparing ideas or argument during the language use. Halliday (2014) and Saragih (2006: 93) state that the development of texts can be conducted through the expansion of clauses covering themes and rhemes. Furthermore, Halliday (2014: 119) adds that the theme in the conversation system is considered as old information (given) and rheme is new information. Yet, both of them become a systemic unit in the presidential candidates' speech act.

The tool of the use of theme-rheme is helpful and beneficial for investigating the patterns of conversations of the candidates, whether the concept offered has logical realization or otherwise contains only political promises. In addition, the pattern of text development in a candidate's conversation can represent the regularity, continuity, and harmony between old and new information so that it can affect the understanding and mindset of the voters and even they switch to vote for them. Here is an example of a development pattern on CDT 2014. (next page) 


\section{Pattern 1}

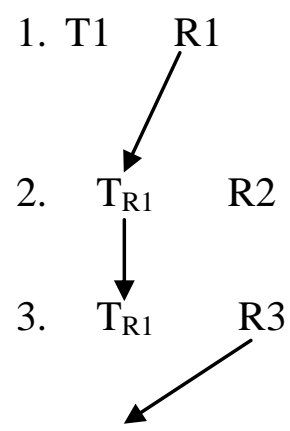

4. $\mathrm{T}_{\mathrm{R} 2} \mathrm{R} 4$ "penambahan penduduk kita sangat luar biasa terjadi ledakan penduduk 5 juta orang tiap tahun lahir//" (the explosion of our population is very extraordinary with 5 million inhabitants per year born)

"justru itulah strategi kami tutup kebocoran amankan kekayaan negara) (that is precisely our strategy to close the leak, secure the state's wealth)

"kita investasikan kepada kesehatan dan pendidikan//" (we invest in health and education)

"dengan kesehatan dan pendidikan kita bisa menumbuhkan kesadaran masyarakat dengan cara persuasif untuk menerima program-program keluarga berencana//" (with health and education, we can raise public awareness in a persuasive way to receive family planning programs)

(DATA 1)

Pattern 1 follow, an inconsistant development structure (zig-zag). The process of development is formed from $\mathrm{R}$ to be $\mathrm{T} 1$ in clause $2 . \mathrm{T} 1$ becomes $\mathrm{T} 2$ in clause 3 . Then there is a focus transition R2 into T3 in clause 4 . The abstraction of pattern 1 is considered more complicated when compared with pattern 2 tending to be symmetrical and simpler.

\section{Pattern 2}

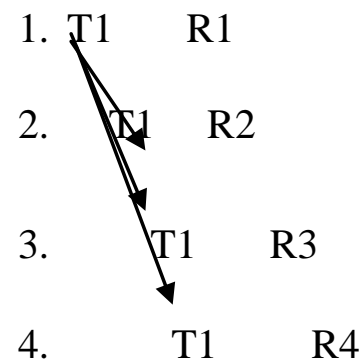

(saya berdiri di sini) (I am standing here)

(karena saya bertemu ibu Eli tukang cuci dari Mando) (because I met Mrs. Eli, a washer from Manado)

(saya bertemu pak Abdullah nelayan dari Belawan) (I met Mr. Abdullah, a fisherman from Belawan)

(saya juga bertemu pak Azad seorang guru di Jawa Barat) (I also met Mr. Azad, a teacher in West Java)

(DATA 2)

Pattern 2 shows the process of developing linear theme, meaning that development occurs quite regularly by starting the focus of old information $\mathrm{T}$ then being $\mathrm{T} 1$ in clause 2 , being $\mathrm{T} 2$ in clause 3 , and being T3 in clause 4 . Development of such a theme is quite systematic and simple.

Pattern 1 and pattern 2 are examplety of forms of text development within the CDT. The existence of these two patterns can represent the way of thinking of the two presidential candidates in expressing their ideas, views, and arguments through the debate. A simple way of thinking tends to make it easier for people to understand their vision - mission, wherlas the complicated one can make it difficult for the people to understand every program proposed by the candidates. 


\section{Results and Discussion}

Text development system is a set of networks of several clauses making the unity of information. Text development can represent the speaker's way of thinking. In addition, the direction of text development can contribute the understanding of the hearers or audiences of information unity. Halliday (2014); Saragih (2006: 93) state that the text development system can be investigated through the progression of the use of theme - rheme. The pattern of text development can be known by positioning the theme - rheme in each clause. As explained previously, that them is a reflection of old information and this rheme is a form of new information, that can determine the purpose of the material development of the utterances uttered by participants. Related to that, the result of PS and JW statement on TDC I and II shows three patterns; namely, Linear, zig-zag pattern and multiple pattern (mixed-pattern). All patterns are derived from the analysis of the utterances of the two presidential candidates at each session or stage of debate.

\subsection{Linear Pattern}

Linear pattern is a form of development of one-way text connecting theme I - theme II theme III - theme IV, and so on or rheme I - rheme II - rheme III - rheme IV, and so on. This pattern of theme is considered a simple pattern since it pictures one-way text development. In addition, linear thematic progression tends not to randomly position the material. It eases audiences or listeners to understand each description of the participant. The analysis of text development pattern on PS and JW statements or utterances in CDT I and II indicates the existence of the use of constant pattern. Based on the examination on the use of linear pattern on the utterances produced by both presidential candidates, two patterns of thematic progression are discovered; namely, linear pattern, and dynamic pattern.

\subsubsection{Constant-Linear Pattern}

The constant linear pattern is a form of text that has not changed in the theme and rheme. It can be stated that there is no development of one clause in the expressed element and the element describing something in the clause. This pattern can align with the form of a clause that is full repetition meaning where a repetition of the whole clause appears. The levels of the use of constant linear pattern on the text development pattern used by both presidential candidates are presented as follows: 
Table 4.1: The Level of the Use of Constant-Linear Pattern by Both Presidential Candidates

\begin{tabular}{cccc}
\hline Candidate & \multicolumn{2}{c}{ Level of the Use } & \multirow{2}{*}{ Number of use (unit of text) } \\
\cline { 2 - 3 } & TDC I & TDC II & \\
PS & - & 1 & 1 \\
JW & 2 & - & 2 \\
\hline
\end{tabular}

The level of the use of the text with constant linear pattern presented in table 4.1 above shows different patterns of text development used by both candidates. It is indicated that JW dominates the use of constant linear patterns with 2 units of text, while constant linear PS is only found in 1 unit of text. This pattern has no development in the theme-rheme. As a result, repetitive information would be obtained by the audiences. Furthermore, the constant linear pattern on the utterances produced by both candidates shows a policy lap. The lap found here determines the purpose of the policies used by the two presidential candidates to lead Indonesia. The example of the text development is presented below.

\section{Prabowo Subianto (PS)}

Units I: "Perbaikan kebijakan pemerintah" (The improvement of government policy)

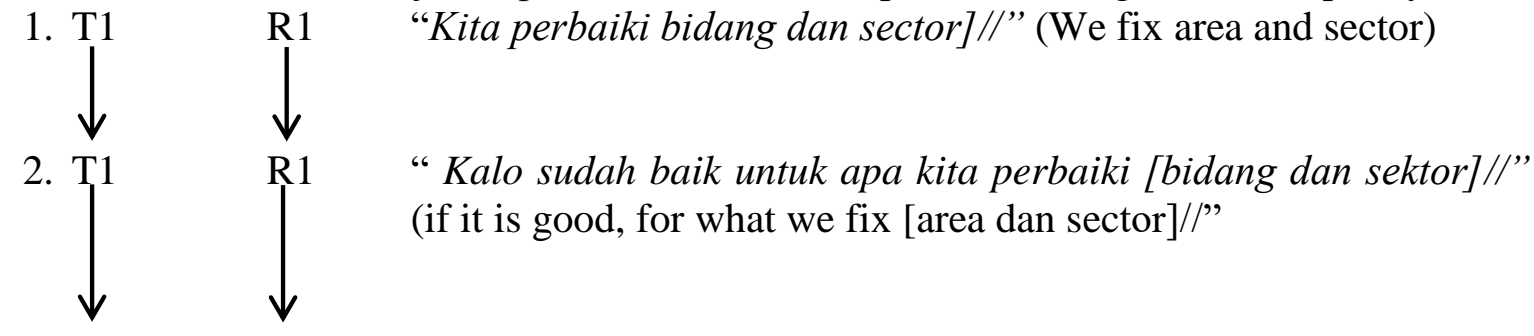

3. T1 R1 "Kalo sudah baik kita pertahankan [bidang dan sektor]//" (If it is $\downarrow \quad \downarrow \quad$ good we maintain [ area and sector])

4. T1 R1 "kita teruskan [bidang dan sektor]//" (We keep it up [area and sector])

5. T2 RT1 "Jadi kebetulan harus diakui [oleh kita] bahwa dalam hal politik luar negeri iya pemerintah SBY//" (So fortunately, it should be admitted [by us] that in terms of international politic yes it is SBY government)

(DATA 3)

The topic of the utterances produced by PS in Data 3 highlights whether or not the improvements to previous government policies on the area or sector are considered productive policies. Besides, the plot of the text does not develop in the aspect of theme and rheme. It can be 
observed from the purpose of the progression of the word kita (we) T1 and the phrase bidang (area) and sektor (sector) as R1 of the first clause are not progressed in the second, third and fourth clauses.

\section{Calon Presiden Joko Widodo (JW)}

Units VI: "Perbaikan sistem pelayanan" (The improvement of service system)
1. T1
$\mathrm{R} 1$
$\downarrow$
"bahwa ini adalah [sistem]//" (that it is a [system])
2. T2
R1
"[kita] membangun sistem//” (we develop system)
3. T2
$\downarrow$
“[kita] membangun sistem//” (we develop system)
4. $\mathrm{T} 2$
$\mathrm{R} 1$
$\downarrow$
5. T1
"dan [kita] mengontrol sistem itu dengan cara apa? Ya dengan sistem kartu ini (sambil menunjukkan kartu ditangan kanan)//" (and how [we] control the system ? yes by this card system-while showing the card on his right hand-) "anggaranya ada//" (there is budget)
6. TR1 RT2<smiles>[AlH2]</smiles>
7. TR1 R3<smiles>[AlH2]</smiles>
8. TR1
"tapi kalo sistemnya tidak dibangun [oleh kita]//" (But if the system is
RT2 not built [by us])
"sistemnya tidak ada manajemen pengawas yang baik//" (The system has no good supervisory management) "sistemnya tidak dikontrol [oleh kita] di lapangan//" (The system is not controlled [by us] in the field)

(DATA 4)

The utterances produced by JW's statement on data 4 is linearly constant, meaning that there is no theme and rheme development or progression in some clauses within a unit of text. The topic of the JW's utterance describes the national service system improvement policy. The service system improvement components include health services through KIS (Kartu Indonesia Sehat/Healthy Indonesia card) and policy monitoring system. 'The text development pattern shows T2 and R1 are not developed or progressed in the first, second, third, and fourth clauses. Subsequently, active clause structure changes into passive; consquently, the development of theme (T1) is reversed into rheme (RT1) and rheme progression (R1) becomes the theme (TR1) in the sixth, seventh, and eighth clauses.

\subsubsection{Dynamic-Linear Pattern}

Dynamic linear pattern is a text form undergoing a development process in the scope of theme or rheme. It reflects that one clause can experience theme-rheme progression or development. From the results of the analysis of the utterances produced by the two candidates 
on CDT I and II, this study only found dynamic linear pattern of text with the rheme development. This pattern focuses on the end of the clause, resulting in the development of the rheme of clause. Conversely, the constant nature of the theme structure indicates the absence of development of old information, leading to information development is resulted. This pattern positions the participant's focus on the explanatory statement in the clause. In addition, the text units of rheme development only undergo the development of the material on the clarifying element of the clause. The level of use of dynamic linear text development pattern on TDC I and II by the two candidates is presented as follows:

Table 4.2: Level of the Use of Dynamic-Linear Pattern by Both Presidential Candidates

\begin{tabular}{cccc}
\hline Candidate & \multicolumn{2}{c}{ Level of the use } & $\begin{array}{c}\text { Number of the use } \\
\text { (unit of text) }\end{array}$ \\
\cline { 2 - 3 } PS & TDC I & TDC II & 9 \\
JW & 3 & 6 & 6 \\
\hline
\end{tabular}

Table 4.2 shows that PS has 9 units of dynamic linear pattern of text, whereas JW has 6 linear pattern text units. It shows that PS is more dominant in using dynamic linear text pattern than JW is. The dynamic linear text pattern has a simple groove, making it easier for every participant to understand. This pattern positions the theme as a constant element and puts dynamic information in the clause. Then, the dynamic linear text pattern has an outreach on some policies submitted by both candidates. The lap shows the goal of the policy which is the priority of both candidates. The examples of dynamic linear text development by the two presidential candidates are presented as follows.

\section{Prabowo Subianto (PS)}

Units III: "Kebijakan pembangunan ekonomi dan kesejahteraan rakyat" (Economy development policy and prosperity)

1. T1 R1 "kami akan dalam 5 tahun meminimalkan korupsi dari APBD dan $A P B N / /$ " (We will minimize corruption from APBD/ Local Government Budget and APBN/National Budget)

2. $\mathrm{T} 1$

$\mathrm{R} 2$

3. $\mathrm{T} 1$ $\downarrow$

4. T1

5. T1 $\downarrow$ "kami akan naikan penghasilan rata-rata rakyat Indonesia 2,5 kali lipat//" (We will increase per-capita income the people of Indonesia 2.5 times)

R3 "Kami akan menambah sawa 2 juta hektar//" (We will add 2 million hectares field)

R4 'kami akan menambah 2 juta hektar untuk bioetanol //P'(We will add 2 million hectares field for bioethanol)

R5 "kami akan membangun $3.000 \mathrm{KM}$ jalan rayal $4.000 \mathrm{KM}$ kereta 
6. T1 R6 "kami akan membuat bank tani dan nelayan dan bank koprasi dan
lembaga tabung haji//" ( We will build bank for farmers,
fishermen, and a cooperative bank and Hajj saving institution )

api/ 8 pelabuhan//" (We will build 3,000 KM highway / 4,000 KM railway / 8 ports)

(DATA 5)

The statement produced by PS in data 5 shows the dynamic linear pattern of text development. Positioning our words as dynamic clauses is regular because it has a one-way direction. The pattern positions the words into of the first clause, $\mathrm{T} 2$ of the second clause, $\mathrm{T} 3 \mathrm{of}$ the third clause, T4 of the fourth clause, T5 of the fifth clause, and T5 of the sixth clause. Then dynamic elements show different information in each clause. The information contains the policy plan of economic development and people's welfare by PS. The plot of dynamic linear development begins with clauses of statements about reducing corruption, increasing per-capita incomes, adding agricultural land, building highways, railway cranes, harbors, farmers and fishermen banks, cooperative banks and hajj savings institutions.

\section{Calon Presiden Joko Widodo (JW)}

Unit 3: "Tekad kepimimpinan JW" (Leadership Determination of JW)

\begin{tabular}{|c|c|c|}
\hline 1. $\underset{\downarrow}{T} 1$ & R1 & $\begin{array}{l}\text { "saya Joko Widodo saya lahir di sini//" (I am Joko Widodo I was born } \\
\text { here) }\end{array}$ \\
\hline 2. T1 & $\mathrm{R} 2$ & "saya besar di sini//” (I grow here) \\
\hline 3. T1 & R3 & "saya dididik [oleh guru] di sini//" (I was educated [by teachers] her) \\
\hline 4. T1 & $\mathrm{R} 4$ & "dan saya seutuhnya adalah Indonesia//" (I am truly Indonesia) \\
\hline 5. T1 & R5 & "saya tegaskan//" (I affirm) \\
\hline 6. $\underset{\downarrow}{\downarrow} 1$ & R6 & $\begin{array}{l}\text { "saya dan pak JK siap memimpin Indonesia//" (I and Mr. JK are ready } \\
\text { to lead Indonesia) }\end{array}$ \\
\hline 7. T1 & R7 & "dan saya tegaskan//" (And I affirm) \\
\hline $\begin{array}{l}\text { 8. T1 } \\
\downarrow \\
\text { 9. T1 }\end{array}$ & R8 & $\begin{array}{l}\text { "bahwa saya hanya tunduk kepada konstitusi//" (that I only stand on } \\
\text { the constitution) } \\
\text { "saya hanya tunduk kepada kehendak rakyat- rakyat Indonesia//" (I } \\
\text { am only loval to the will of Indonesia citizens) }\end{array}$ \\
\hline
\end{tabular}

(DATA 6) 
Data 6 contains the utterances produced by JW that shows dynamic linear pattern. The topic of the utterances is his leadership determination if he would be elected as president 2014 - 2019. The text development begins with the use of the word saya (I) which belongs to single inclusive word. The word saya (I) has position as T1 of first clause, T2 of the second clause, T3 of the third clause, T4 of the fourth clause, T5 of the fifth clause, T6 of the clause six, T7 of the seventh clause, T8 of the clause eighth, and T9 of the ninth clause. Each theme of the JW utterance focuses on his determination to lead the nation and state because he was born and raised in Indonesia, the place where he got education, and he affirmed that he only stood on the constitution and the people of Indonesia.

\subsection{Zig-zag Pattern}

Zig-zag pattern is a form of development of two-way text that connects the theme and dynamic into a flow of textual thinking, such as theme I which becomes dynamic II, dynamic II which becomes theme III, theme III which becomes dynamic IV, and so on. Statements with intricate patterns are complex, meaning the text of a speaker must associate the theme and dynamic elements in rotation in a unit of text, while the listener must carefully listen to the theme and dynamic descriptions alternately. From the results of PS and JW text unit analysis on TDC I and II, this study finds the level of usage use of the Zig-zag pattern, as follows.

Table 4.3: Level of the Use of Zig-zag Pattern by Both Presidential Candidates

\begin{tabular}{cccc}
\hline Candidate & \multicolumn{2}{c}{ Level of the Use } & Number of use \\
\cline { 2 - 3 } & TDC I & TDC II & (unit of text) \\
PS & 2 & 1 & 3 \\
JW & - & - & - \\
\hline
\end{tabular}

Table 4.3 shows the level of the use of text with a Zig-zag pattern only by the PS. PS has 2 units of the use of text, while JW has no use, meaning that the PS dominates the statement with a Zig-zag pattern. The form of a Zig-zag pattern in a unit of text generally constructs the theme into dynamic information, instead dynamically into the theme information. Both forms of this construction require the listening and understanding of listeners to the policies presented by the presidential candidate. The data can be seen in this scheme below.

\section{Prabowo Subianto (PS)}

Units 1 : "tujuan bernegara untuk kemakmuran" (The purpose of the state for prosperity)

1. T1 R1 "Kita mengerti [tujuan negara] //" (We understand [the purpose of this country])

2. TR1 R2 "tujuan kita bernegara adalah [kemakmuran]// (The purpose of our country is [prosperity]) 
3. TR2 R3 "Untuk kemakmuran bersama// (For mutual prosperity)

4. T1 R2 "masalahnya adalah [upaya] bagaimana mencapai itu [kemakmuran]?//" ("The problem is [effort] how to achieve that [prosperity]?)

(DATA 7)

PS's statement in data 7 mixed pattern. Text information obtained is the purpose of the country to achieve the nation's prosperity. The description of this information uses the progression of R1 - TR1 and R2 - TR2. It means that the word tujuan (purpose) is the first dynamic undergoing the process of putting it into a dynamic first theme in the second clause. Furthermore, the word kemakmuran (prosperity) as the second dynamic in the second clause becomes the second dynamic theme in the third clause. This pattern shows a Zig-zag pattern in positioning a dynamic theme in each clause.

\subsection{Multiple Pattern}

The multiple pattern is a composite of linear pattern and Zig-zag pattern of text within a single unit of text. This study found a tendency to use linear or zig-zag patterns within a unit of text. This research divides the two forms of mixed patterns, i.e., mixed-linear patterns and mixed- Zigzag patterns.

\subsubsection{Mixed-Linear Pattern}

The mixed-linear pattern is a linear pattern of text between linear and Zig-zag, but it is dominated by the linear patter. This pattern has the nature of the text that is considered more easily understood than the Zig-zag pattern because the speaker will tend to speak orderly and facilitate the listener to follow the way of participants' utterances. From the analysis of text pattern of PS and JW's statement in CDT I and II, this research found the level of the use of text of mixed linear pattern as follows.

Table 4.4 : Level of the Use of Mixed-Linear Pattern by Both Presidential Candidates

\begin{tabular}{cccc}
\hline Candidate & \multicolumn{2}{c}{ Level of the Use } & Number (unit of text) \\
\cline { 2 - 3 } & TDC I & TDC II & \\
PS & 16 & 20 & 36 \\
JW & 26 & 26 & 52 \\
\hline
\end{tabular}

Table 4.4 above presents the level of use of linear mixed pattern of a text. From the analysis results in the table, JW dominated the use of linear mixed pattern of text totaling 52 units of text, while PS only used 36 units of text. Therefore, JW's utterance was considered by other 
participants to be simpler than the PS's utterance since the nature of the linear text leads the listener to understanding the text content simply. The data are described as follow.

\section{Prabowo Subianto (PS)}

Unit 3 : "pengamanan kekuatan dan kekayaan nasional” (The security of National strength and wealth)

1. T1 R1 Nah karena itu politik luar negeri mau tidak mau adalah cermin dari $\downarrow \quad \quad k o n d i s i$ dalam negeri//" (Well, therefore, international politic will inevitably

2. T1 R2 be a reflection of domestic conditions

R2 "Politik luar negeri tidak akan berarti kalo kekuatan dalam negeri kita
lemah//" (Foreign/international politic will be meaningless if our domestic
strength is weak)

3. TR2 R3 Karena itu saya terus menerus selalu bicara tentang bagaimana Indonesia mengamankan kekuatan nasionalnya dan mengamankan kekayaan nasionalnya//" (Therefore I keep talking constantly about how Indonesia secures its national power and secures its national wealth)

4. T2 R3 "bagaimana Indonesia mengamankan kekuatan nasionalnya//" (How $\downarrow \quad$ Indonesia secures its national power)

5. T3 R3 “ dan [bagaimana] mengamankan kekayaan nasionalnya//” (And [how] secured its national wealth)

6. TR3 R4

"[kekuatan dan kekayaan nasional] ini yang menjadi fundamental//"

(This [national strength and wealth] is fundamental)

(DATA 8)

Data 8 is categorized as the same category as data 384 which is a mixed- linear text pattern. The topics of utterances were delivered by PS on questioning about how to improve people's welfare? This question was asked by PS to JW. The question addressed by PS includes the importance of maintaining or securing national strength and wealth to strengthen the function and influence of The Indonesian International politics. The flow of information in the text begins with the phrase politik luar negeri (international politics) as the initial theme and kekuatan (strength) - kekayaan nasional (national wealth) as dynamic. The information process shows the first clause T1 - T1 the second clause, R2 second clause - TR2 third clause, R3 third clause - R3 fourth clause, and R3 of the fifth clause - TR3 the sixth clause. 


\section{Joko Widodo (JW)}

Units 4 : "peningkatan peran Dubes" (The role empowerment of ambassadors)
1. T1 R1 "kita harus diperkuat bagi dubes-dubes//" (We must be strengthened for
the ambassadors)
2. TR1 R2 "[dubes-dubes] yang berada di Asia//” ([Ambassador] in Asia)
3. TR1 R3 "artinya apa dubes-dubes kita harus menjadi marketer//" ( that means $\downarrow \quad$ what, our ambassadors should be marketer)
4. TR1 R4 “[dubes-dubes] harus mampu memarketing [produk-produk]//” $\downarrow$ ([ambassadors] should be able to market products)

5. TR1 R5

"[dubes-dubes] mampu memasarkan produk-produk//” ([Ambassadors] are able to market products)
6. TR5 R6 $\downarrow$
"[produk-produk] yang ada di daerah-daerah//” ([Products] that exist in the regions)
7. TR5 R7 "baik produk industri kecil baik produk-produk UKM yang sebetulnya ini mempunyai daya saing tinggi karena harganya yang masih sangat kompetitif//" (Both small industry products both Small and Medium Business products that actually have a high competitiveness because the price is still very competitive)

8. T2 R7 "harganya punya daya saing//" (the price is still very competitive)

(Data 9)

The statement delivered by JW in data 9 is indicated as a text developed by a linear mixture pattern. The topic of the text produced by JW stated the role empowerment of Ambassador. The Ambassador was expected by JW to become a market player, meaning that Ambassador should be able to market local products as well as to enhance competitive competitiveness of Small and Middle Economy or Business products. Furthermore, the dynamic theme line shows the word of duta besar (ambassador) to dynamic in R1 of the first clause - TR1 of the second clause - TR1 of the third clause - TR1 of the fourth clause - TR1 of the fifth clause. The words produk-produk (products) and harga (prices) become dynamic on R5 fifth clause - TR5 of the fifth clause and R7 becomes TR7 - R7 of the eighth clause. It is alarmed that the text unit of data 6 has text that starts from a dynamic then becomes a theme; therefore, this research did not find any form originated from the theme. 


\subsubsection{Mixed- Zig-zag Pattern}

The mixed-Zig-zag pattern is composed of Zig-zag and linear text patterns, but it is dominated by Zig-zag patterns. The nature of this type of text is considered complicated because it has irregular progression and tends to start from a dynamic and each track tends to load from the theme - dynamic - theme -Dynamic, and so on. From the results of the analysis, this study toward the text pattern of utterances produced by PS and JW in CDT I and II. The level of use of mixed Zig-zag patterns dominated by Zig-zag pattern can be seen in table 6.15 below.

Table 6.15: Level of the use of mixed zig-zag pattern by both Presidential Candidates

\begin{tabular}{|c|c|c|c|}
\hline \multirow[t]{2}{*}{ Candidate } & \multicolumn{2}{|c|}{ Level of Use } & \multirow{2}{*}{$\begin{array}{c}\text { Number of Use } \\
\text { (unit of text) }\end{array}$} \\
\hline & TDC I & TDC II & \\
\hline PS & 7 & 5 & 12 \\
\hline JW & 5 & 6 & 11 \\
\hline
\end{tabular}

Table 6.15 shows the use of mixed Zig-zag pattern of text produced by both candidates. PS dominates the use of linear mixed pattern of text. The level of use by PS to taked 12 units of text, whereas in the JW statement there are found 11 units of text were found. The example of the data is presented as follows.

Prabowo Subianto (PS)

Units 3: "penanganan ancaman nansional" (Handling national threats)

1. T1 R1 "nggak...nggak ancaman terbesar ya//”" (No... Not the biggest threat )<smiles>CC</smiles>

2. T2 RT1

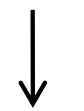

3. T3 RT1

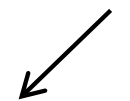

4. $\mathrm{T} 1 \mathrm{R} 2$

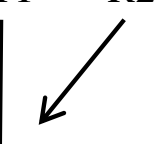

5.

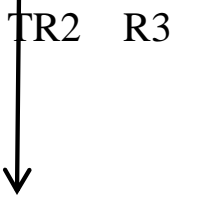

6. $\mathrm{T} 1 \mathrm{R} 4$

7. $\mathrm{T} 4$<smiles>[Te][Te]</smiles>

"baik kalo begitu saya simpulkan ancaman terbesar dari luar negeri dan ancaman terbesar dari dalam negeri//" (Well so I conclude the greatest threat from abroad and the greatest threat from within the country)

"baik saya liat ancaman terbesar dari dalam negeri//" (Well I see the biggest threat from within the country)

"[ancaman terbesar dari dalam negeri] adalah bahwa negara-negara e.. lain atau negara-negara tertentu//" ("[The greatest threat from within the country] is that of other countries or certain countries)

"[negara-negara e..lain atau negara-negara tertentu] yang akan mengklaim wilayah nasional kita//” ("[Other countries or certain countries] that will claim our national territory

"dan [ancaman] ini menurut saya//" (And the [threat] is in my opinion)

“harus kita hadapi [ancaman]//” (Should we face [threat]) 
8. T1 R5 "kalu ancaman terbesar dari dalam negeri menurut saya//" (the greatest threat from our country in my opinion)

9. T1 R6 "[ancaman terbesar dari dalam negeri] adalah kemiskinan//" "[The greatest threat from within the country] is poverty)

(DATA 10)

The text unit in data 10 is linearly mixed. PS declares policy on the handling of national threats. Threats can be sourced from within and outside the country. The domestic threat is the biggest threat to the government. The form of threat is poverty. The government must be able to handle the problem of poverty. It is followed by the threat of foreign claim of the territory of Indonesia by the foreign countries. This issue often occurs among neighboring countries. The information progression in the text starts from the word ancaman (threat) to the theme in the T1 of first clause - R1 of the second clause - R1 of the third clause - T1 of the fourth clause - T1 of the clause - R1 of seventh clause - T1 of the eighth clause - T1 of the ninth clause. The words negara-negara lain (other states) become dynamic in $\mathrm{R} 2$ of the fourth clause - T2 of the fifth clause.

\section{Joko Widodo (JW)}

Units 4: "sistem pertahanan cyber dan hybrid" (Cyber and hybrid defence system)

1. T1 R1 "Oleh sebab itu ke depan kita harus mempunyai sebuah sebuah dron atau sebuah ee... pesawat tanpa awak//" (Therefore in the future we must have a dron or an ee ... unmanned aircraft)

2. TR1 R2 “[sebuah dron atau sebuah ee... pesawat tanpa awak] yang kita pasang di tiga kawasan//" ("[A dron or an ee ... unmanned aircraft] that we install in three regions

3. TR1 R3 “dan dengan dron ini kita bisa melihat [kekayaan maritim kita]//” (And with this drone we can see [our maritime property])

4. TR3 R4 “di mana ada kekayaan maritim kita//” (where our maritime wealth is)

5. TR4 R5 "[kekayaan maritim kita] yang diambil oleh kapal-kapal//" ("[Our maritime wealth] taken by ships) 
6. TR5 R6 “[kapal-kapal] yang masuk ke area perairan kita//” ("[Ships] coming into our water area)

7. TR1 R7 "Dron ini ada tiga kegunaan yang pertama untuk pertahanan kita//" (This Dron has the first three uses for our defense)

8. T2 R8 "yang kedua [kita] bisa untuk mengejar [ilegal fishing]//” (The second [we] can to catch [illegal fishing])

9. T 3 R8 “kalo ada ilegal fishing/P’ (If there is illegal fishing)

10. RT1,R9 "kemudian yang ketiga juga bisa kita pakek//" (Then the third one can also we use)

11. TR9 R10 "untuk [kita] mengejar/ [ilegal fishing]//” (For [us] to chase [[illegal fishing])

12. T4 R8 "kalau ada ilegal loging//” (If there is illegal loging)

(DATA 11)

The text pattern in data 11 is linear mixed pattern of text. JW informed topics of information about cyber and hybrid defense systems. To realize this policy, JW required Indonesia to have dron (drone) or unmanned aircraft. For JW, the dron has numerous functions such as to monitor Indonesia's maritime wealth, pursue the perpetrators of illegal fishing and illegal logging in Indonesia's forests. The flow of each utterance on the unit of text begins with the word dron ... peawat tanpa awak (unmanned aircraft) becomes dynamic in R1 of the first clause - T1 of the second clause - T1 of the third clause - T1 of the seventh clause - R8 of the eighth clause - R8 of the ninth clause - R10 of the eleventh clause - R8 of the twelfth clause. The word kekayaan maritim (maritime wealth) becomes dynamic in R3 of the third clause - T3 of the fourth clause. The word ships become dynamic in R5 of the fifth clause - T5 of the sixth clause. The word kita (Our) becomes dynamic in R9 of the tenth clause - T9 of the eleventh clause. Notes on data 11 is that it was not found a form originated by theme, so the mixed Zig-zag pattern is sourced from the progression of dynamic-theme-dynamic.

\section{Novelties}

The text development system has two other developmental units; there are the pattern of linear theme (i.e., static and dynamic) and mixed pattern (multiple pattern) with the direction of theme-rheme development. The pattern can be presented as follows.

a) Static-Linear sub-pattern tends to be fully repetitive on the theme-rheme section such as: $\mathrm{T} 1_{\mathrm{I}}>$ $\mathrm{T} 1_{\text {II }}>\mathrm{T} 1_{\text {III }}>\mathrm{T} 1_{\text {IV }}$ and $\mathrm{R} 1_{\text {I }}>\mathrm{R} 1_{\text {II }}>\mathrm{R} 1_{\text {III }}>\mathrm{R} 1_{\text {IV }}$ 
b) Dynamic-Linear sub-pattern tends to be partially repetitive on one the theme-rheme section , such as : $\mathrm{T} 1_{\mathrm{I}}>\mathrm{T} 1_{\mathrm{II}}>\mathrm{T} 1_{\mathrm{III}}>\mathrm{T} 1_{\mathrm{IV}}$ and $\mathrm{R} 1^{\wedge} \mathrm{R} 2^{\wedge} \mathrm{R} 3^{\wedge} \mathrm{R} 4$ or $\mathrm{T} 11^{\wedge} \mathrm{T} 2^{\wedge} \mathrm{T} 3 \wedge$ T4 and $\mathrm{R} 1_{\mathrm{I}}>\mathrm{R} 1_{\mathrm{II}}$ $>\mathrm{R} 1_{\text {III }}>\mathrm{R} 1_{\text {IV. }}$

c) The Mixed-Linear sub-pattern is composed of linear and Zig-zag pattern, but it is dominated

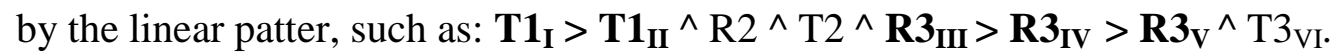

d) The Mixed-Zig-zag sub-pattern is composed of Zig-zag and linear text patterns, but it is dominated by Zig-zag patterns such as: $\mathbf{R 1} \wedge \mathrm{T}_{\mathrm{II}}>\mathrm{T}_{\mathrm{III}} \wedge \mathbf{R 3}^{\wedge} \mathbf{T 3}_{\mathrm{IV}} \wedge \mathbf{R 4} \wedge \mathbf{T} 4_{\mathbf{V}} \wedge \mathbf{R 5} \wedge$ T5 5 .

\section{Conclusion}

The text development system on the utterances produced by PS and JW has a difference. It was found that dynamic linear text development pattern (e.g. $\mathrm{T} 1_{\mathrm{I}}>\mathrm{T} 1_{\mathrm{II}}>\mathrm{T} 1_{\mathrm{III}}>\mathrm{T} 1_{\mathrm{IV}}$ and $\mathrm{R} 1 \wedge \mathrm{R} 2^{\wedge} \mathrm{R} 3{ }^{\wedge}$ $\mathrm{R} 4$ and $\mathrm{R} 1_{\mathrm{I}}>\mathrm{R} 1_{\mathrm{II}}>\mathrm{R} 1_{\mathrm{III}}>\mathrm{R} 1_{\mathrm{IV}}$.) was tended to be used by PS. This pattern reaches the range of statements covering the policy of economy development and national welfare and procurement of armaments. He also tended to use the development of texts with a Zig-zag pattern (e.g. pattern $\mathrm{T} 1_{\mathrm{I}}>\mathrm{R} 1_{\mathrm{II}}$ $>\mathrm{T} 1_{\mathrm{III}}>\mathrm{R} 1_{\mathrm{IV}}$ ) with range of statements including the purpose of the state for prosperity and security. Meanwhile, JW tended to use a constant linear text development pattern with a range of statement range including: improvement of national service system (e.g. patterns $\mathrm{T} 1_{\mathrm{I}}>\mathrm{T} 1_{\mathrm{II}}>\mathrm{T} 1_{\mathrm{III}}>\mathrm{T} 1_{\mathrm{IV}}$ dan $\mathrm{R} 1_{\mathrm{I}}>$ $\mathrm{R} 1_{\text {II }}>\mathrm{R} 1_{\text {III }}>\mathrm{R} 1_{\mathrm{IV}}$.) And development of text with a mixed-linear pattern covering the improvement of minimum wage policies and the role empowerment of ambassadors (e.g. $\mathbf{T} 1_{I}>\mathbf{T 1}_{\text {II }} \wedge$ R2 ${ }^{\wedge} \mathrm{T} 2^{\wedge} \mathbf{R} 3_{\text {III }}>$ $\mathbf{R} 3_{\text {IV }}>\mathbf{R} 3_{V}^{\wedge} \mathrm{T}_{\mathrm{VI}}$.)

\section{REFERENCES:}

Ajilore, Oluwateniola Oluwabukola. 2015. Acclaims, Attacks and Deferences in Nigerian Gubernatorial Debate. In Discurse \& Communication Vol. 9 (1) . London: Sage London: Sage, p: $3-18$.

Benoit, William L. dan David Airne. 2005. A Funcyional Analysis of American Vice Presidential Debates. In Argumentation and Advocacy Vol.41(spring).US: Montana, p: $225-236$.

Bhattarai, Keshab, Paul Bachman, Frank Conte, Jonathan Haughton, Michael Head, and David G. Tuerck. 2018. Tax Plan debates in the US presidential election: A dynamic CGE analysis of growth and redistribution trade-offs. Economic Modelling. 68(1):529-542. 
Halliday, M.A.K.. 1985. "Systemics Background”. In: Benson, J. D. and W.S. Greaves, editors. Systemic Perpectives on Discourse, Vol. I, Norwood: Ablex Publishing. p: 1-15.

Halliday, M.A.K.. 1991. An Introduction to Functional Grammar $2^{\text {th }}$. London: Edward Arnold.

Halliday, M.A.K.. 2004. An Introduction to Functional Grammar $3^{\text {th }}$. Revised by Christian M.I.M Matthiessen. London: Hodder Arnold.

Halliday, M.A.K. 2014. Introducing to Functional Grammar $4^{\text {th }}$. Revised by Christian M.I.M. Matthiessen. London: Routledge.

Jones, Jason dan Shận Wareing. 2007. Bahasa dan Politik. (Sunoto,dkk., Pent). Dalam Abd. Syukur Ibrahim, editor. Bahasa, Masyarakat, dan Kekuasaan. Yogyakarta: Pustaka Pelajar. Hal: 49-76.

Koussouhon, Leonard A. dan Ashani M. Dossoumou. 2015. Political and Ideological Commitments: A Systemic Funtional Linguistics and Critical Discourse Analysis of President Buhari's Inaugural Speech. In International Journal of Linguistics and Comunication (IJLC) Vol.3(2),P: $24-34$.

Mahsun. (2007). Edisi Revisi: Metode Penelitian Bahasa: Tahapan Strategi, Metode, dan Tekniknya. Jakarta: PT RajaGrafindo Persada. Miles, Matthew B. Dan A. Michael Huberman.1992. Analisis Data Kualitatif: Buku Sumber tentang Metode-metode Baru. Diterjemahkan oleh Tjejep Rohendi R. Jakarta: UI-Press.

Miles, Matthew B. dan A. Michael Huberman.1992. Analisis Data Kualitatif: Buku Sumber tentang Metode-metode Baru. (Tjejep Rohendi R., Pentj) Jakarta: UI-Press.

Orwell, G. 1986. Politics and the English Language In: Exploring Language. In Goshgarian, G., editor. Boston: Little, Brown, and Company.

Potter, Lorena. 2016. Ideological Representations and Thema - Rhema Analysis in English and Arabic News Reports: A Systemic Functional Approach. In Functional Linguistics Vol.3(5)., p: $1-20$.

Purba, Rosanti Anugrah Nurjannah. Berperang dengan Saudara Sendiri. http://news.okezone.com/read/2014/08/23/367/1028783/. Diakses tanggal 10 Januari 2015.

Saragih, A. 2006. Bahasa dalam Konteks Sosial: Teori Linguistik Fungsional Sistemik terhadap Tata Bahasa dan Wacana. Medan: Pascasarjana Unimed Press.

Sinar, Tengku Silvana. 2012. Teori dan Analisis Wacana: Teori Linguistik Sistemik Fungsional. Medan: CV Mitra.

Sudaryanto. 2015. Metode dan Aneka Teknik Analisis Bahasa: Pengantar Penelitian Wahana Kebudayaan secara Linguistik. Yogyakarta: Sanata Dharma University Press. 
Young, Lynne. 2011. Systemic Functional Linguistics. In James Simpson, editor. The Routledge Handbook of Applied Linguistics. London: Routledge. p: 625-637.

\section{Acknowledgements}

My gratitude is delivered to the team of examiners, Prof. Dr. Aron Meko Mbete, Prof. Dr. I Nengah Sudipa, M.A., Prof. Dr. I Wayan Simpen. M.Hum. Dr. Putu Sutama, M.S., and Dr. Made Sri Satyawati, S.S., M.Hum., for their advice, criticism, motivation, appreciation, and moral support, so that this research can be accomplished. 